\title{
Protein Dynamics in Iron-Starved Mycobacterium Tuberculosis Revealed by Turnover and Abundance Measurement Using Hybrid-Linear Ion Trap-Fourier Transform Mass Spectrometry
}

\author{
Prahlad K. Rao ${ }^{1}$, G. Marcela Rodriguez ${ }^{2}$, Issar Smith ${ }^{2}$, and Qingbo Li ${ }^{1,3}$, \\ ${ }^{1}$ Center for Pharmaceutical Biotechnology, College of Pharmacy, University of Illinois at Chicago, \\ Chicago, Illinois 60607 \\ ${ }^{2}$ TB Center, The Public Health Research Institute, University of Medicine and Dentistry of New \\ Jersey, Newark, New Jersey 07103 \\ ${ }^{3}$ Department of Microbiology and Immunology, College of Medicine, University of Illinois at Chicago, \\ Chicago, Illinois 60607
}

\begin{abstract}
To study the proteome response of Mycobacterium tuberculosis H37Rv to a change in iron level, iron-starved late-log-phase cells were diluted in fresh low- and high-iron media containing $\left[{ }^{15} \mathrm{~N}\right]$ labeled asparagine as the sole nitrogen source for labeling the proteins synthesized upon dilution. We determined the relative protein abundance and protein turnover in M. tuberculosis H37Rv under these two conditions. For measurements, we used a high-resolution hybrid-linear ion trap- Fourier transform mass spectrometer coupled with nanoliquid chromatography separation. While relative protein abundance analysis shows that only 5 proteins were upregulated by high iron, 24 proteins had elevated protein turnover for the cells in the high-iron medium. This suggests that protein turnover is a sensitive parameter to assess the proteome dynamics. Cluster analysis was used to explore the interconnection of protein abundance and turnover, revealing coordination of the cellular processes of protein synthesis, degradation, and secretion that determine the abundance and allocation of a protein in the cytosol and the extracellular matrix of the cells. Further potential utility of the approach is discussed.
\end{abstract}

\section{INTRODUCTION}

As for most pathogens, Mycobacterium tuberculosis has to sequester low levels of available iron from infected hosts to sustain essential cellular functions. ${ }^{1,2}$ While iron is essential, excess iron may be toxic to the organism due to potential damage by reactive oxidative species catalyzed by Fe(II) in the Fenton reaction. Thus, iron has a critical role in infectious diseases, requiring tight regulation not only to ensure sustainable iron level but also to prevent excess iron that can initiate lethal reactions in the pathogen. ${ }^{3,4}$

Early epidemiological surveys demonstrated the association between tuberculosis and irondeficiency anemia due to impaired immunological response. ${ }^{5}$ Contrary to the intuition that iron supplement might improve a host's ability to fight against the infection, later studies ${ }^{6}$ have confirmed earlier examples of enhancement of infection by iron supplement. ${ }^{4}$ This reflects the complex role that iron plays in host-pathogen interaction. 
Mycobaterial iron acquisition pathways have been a sought-after target for designing new drugs against tuberculosis and plague. ${ }^{7-9}$ Genes involving iron-dependant gene expression and iron metabolism have been studied by genetics, microarray, and bioinformatics. ${ }^{3}, 10-15$ On the contrary, a much smaller effort has been put into investigating the mycobacterial proteome under iron-regulated conditions ${ }^{16}$

We previously reported a global protein turnover approach to investigate the proteome response to iron limitation in Mycobacterium smegmatis, providing useful insight into the probable drug resistance mechanism inflicted by iron limitation. ${ }^{17}$ In this work, we further develop this method by combining both protein abundance and turnover measurements to monitor the response to a change in iron level by the M. tuberculosis H37Rv proteome.

In this study, we investigate the response of the H37Rv proteome when iron-starved late-logphase cells were diluted in fresh high-iron medium, using those diluted in fresh low-iron medium as control. $\left[{ }^{15} \mathrm{~N}\right]$ labeled asparagine was used to label proteins synthesized after dilution. Several techniques are used to achieve this goal, including protein absolute ${ }^{18,19}$ and relative ${ }^{20,21}$ abundance measurement, protein turnover analysis, ${ }^{17,} 22$ and cluster analysis. ${ }^{23}$, ${ }^{24}$ Global protein pattern change in several dimensions of measurement is evaluated by cluster analysis, providing interesting insight into the interconnection of protein synthesis, degradation, and secretion that determine the abundance and allocation of a protein in the cytosol and the extracellular matrix of the cells.

\section{MATERIALS AND METHODS}

\section{Chemicals, media, and bacterial strain}

Ninety-eight atomic percent (98At\%) $\left[{ }^{15} \mathrm{~N}\right]$ labeled asparagine was purchased from Sigma (St. Louis, MO). Sequencing grade trypsin was obtained from Promega (Madison, WI). M. tuberculosis $\mathrm{H} 37 \mathrm{Rv}$ was obtained from American Type Culture Collection (Rockville, Md). Ammonium bicarbonate, acetonitrile, and other chemicals were purchased at certified ACS or reagent grade from Fisher Scientific (Pittsburgh, PA).

\section{Cell culturing, metabolic labeling, and sample preparation}

M. tuberculosis $\mathrm{H} 37 \mathrm{Rv}$ was grown in a defined low-iron (LI) medium as previously described, ${ }^{10}$ which contained $0.5 \%(\mathrm{wt} / \mathrm{vol})$ asparagine as the only nitrogen source. Initial LI culture was grown from O.D. 0.1 to late log phase at O.D. 0.77. An aliquot of this late-log-phase culture was diluted to O.D. 0.1 in two 50-ml fresh minimal media respectively. One of the fresh medium had the exact chemical composition as the defined LI medium except that the $0.5 \%$ (wt/vol) asparagine was replaced by its $98 \mathrm{At} \%\left[{ }^{15} \mathrm{~N}\right]$ labeled counterpart. This culture was called $\left[{ }^{15} \mathrm{~N}\right] \mathrm{LI}$ medium. The other fresh medium was essentially the same as the $\left[{ }^{15} \mathrm{~N}\right] \mathrm{LI}$ medium except that $50 \mu \mathrm{M}$ ferric chloride was added. This culture was called $\left[{ }^{15} \mathrm{~N}\right]$ high-iron (HI) medium. Both $\left[{ }^{15} \mathrm{~N}\right]$ cultures were allowed to grow for $24 \mathrm{~h}$ and had reached an O.D. of 0.3 . Cells were collected by centrifugation and resuspended in $0.5 \mathrm{ml}$ of SDS/PAGE gel electrophoresis buffer containing 2\% SDS. The bacteria were heat-killed at The Public Health Research Institute and shipped on dry ice to University of Illinois at Chicago.

The cell suspension solutions were thawed and further heated at $95^{\circ} \mathrm{C}$ for $5 \mathrm{~min}$, chilled on ice, and vigorously agitated for $2 \mathrm{~min}$ at maximum speed with bead beating in a Mini-BeadBeater ${ }^{\mathrm{TM}}$ (BioSpec, Bartlesville, OK). The cell lysates were cleared in a benchtop Eppendorf centrifuge (Fisher Scientific) at 13,000g for $30 \mathrm{~min}$, and quantified by a BCA Protein Assay kit (Pierce, Rockford, IL). The concentration of the protein extract was 3.0 and $3.5 \mathrm{mg} / \mathrm{ml}$ for the LI and HI cells respectively. 
From each of the LI and HI protein extracts, an aliquot containing $50 \mu \mathrm{g}$ of protein was taken for acetone precipitation by adding $4 \mathrm{x}(\mathrm{vol} / \mathrm{vol})$ acetone. The precipitated protein pellets were washed and redissolved in about $10 \mu \mathrm{l}$ buffer consisting of $0.05 \%$ SDS, $50 \mathrm{mM}$ Tris, $5 \mathrm{Mm}$ EDTA and $6 \mathrm{M}$ urea. After the protein pellets dissolved, the protein solutions were diluted by $6 \mathrm{x}$ with $25 \mathrm{mM}$ ammonium bicarbonate. Sequencing grade trypsin was added into each sample at approximately $1: 20$ enzyme/protein ratio. The mixtures were incubated at $37^{\circ} \mathrm{C}$ for $12 \mathrm{~h}$, and acidified by $5 \%$ formic acid. Each sample was purified using a ZipTip ${ }_{\mathrm{C} 18}$ tip (Millipore, Billerica, MA). The bound peptides were eluted with $15 \mu$ l elution solution of $50 \%$ acetonitrile and $0.1 \%$ TFA. Each peptide eluent was further diluted by $10 \mathrm{x}$ with a solution containing $0.1 \%$ TFA and $5 \mathrm{mM}$ DTT, and submitted to the Research Resource Center of University of Illinois at Chicago for protein identification on a hybrid-linear ion trap-Fourier transform mass spectrometer (LTQ-FT) coupled with nanoliquid chromatography (nanoLC) separation system.

\section{Mass spectrometry analysis}

The HI and LI peptide solutions were separated on a $75-\mu \mathrm{m}$ i.d. C18 reverse phase column with a $5-35 \%$ acetonitrile (vol/vol) gradient in $0.1 \%$ TFA over $60 \mathrm{~min}$ and detected by the LTQ-FT. Each sample was analyzed in triplicate injections with $30 \mu \mathrm{l}$ per injection. The LTQFT was operated in a data-dependant acquisition mode with up to 10 MSMS spectra acquired after each FTMS scan. The acquired RAW data files were searched against the $M$. tuberculosis H37Rv database (Sanger Institute, www.sanger.ac.uk) in BioWorks (Finnigan, San Jose, CA). Two searches were done, with one corresponding to $\left[{ }^{14} \mathrm{~N}\right]$ and the other $\left[{ }^{15} \mathrm{~N}\right]$ labeling. The precursor ion tolerance was set to $\pm 1.5 \mathrm{Da}$ and digestion enzyme was designated as trypsin with 2 missed cleavages allowed. Peptide and protein probabilities were calculated in BioWorks. Only peptides with $p<0.01$ were used for subsequent quantitation analysis.

The triplicate injections for the HI sample were named HI-Inj1, HI-Inj2, and HI-Inj3. The triplicate injections for the LI sample were named LI-Inj1, LI-Inj2, and LI-Inj3.

\section{Data analysis}

After database search for peptide/protein identification with BioWorks, isotopologue profiles, protein abundance, and protein turnover were further analyzed as described in the following. The following described procedures were carried out in Matlab v7.2 (MathWorks, Natick, MA) and Microsoft Excel. ${ }^{17,} 20$

Isotopologue profiles-Isotopologue profiles were examined before defining the isotopomer ranges for quantifying a peptide charge state (PCS). ${ }^{17}$ The abundance of each isotopomer in an isotopologue was estimated by the extracted ion chromatographic (XIC) intensity of that isotopomer integrated over a $1.5 \mathrm{~min}$ window in the LC elution time dimension and the full width of the isotopomer peak in the $\mathrm{m} / \mathrm{z}$ dimension. The method of estimating peptide abundance by integrating the ion intensities over a space defined by the $\mathrm{m} / \mathrm{z}$ dimension and the LC elution time dimension has well been illustrated in the accurate mass and time tag (AMT) strategy for label-free quantitation. ${ }^{25,} 26$ The abundance of a PCS was estimated by the sum of XIC intensities from isotopomers under a defined isotopologue profile.

As an example, Figure 1 illustrates the isotopologue profiles of the tryptic PCS VQFQSGGANSPALYLLDGLR ( $\mathrm{MH}_{2}{ }^{2+}, 26 \mathrm{~N}$ atoms) from fibronectin-binding protein A (Rv3804c; FbpA). $A_{\mathrm{L}, \mathrm{PCS}}$ represents the XIC intensity of the old fraction of the peptide being carried over from the late-log-phase cells and surviving degradation/secretion after the cells were resuspended into the fresh $\left[{ }^{15} \mathrm{~N}\right]$ labeled media. $A_{\mathrm{M}, \mathrm{PCS}}$ represents the XIC intensity of the new fraction of the peptide being de novo synthesized after the cells were resuspended into the fresh $\left[{ }^{15} \mathrm{~N}\right]$ labeled media. Figure S1 (SI) further shows the average isotopomer profiles 
and selected isotopomer ranges for calculating $A_{\mathrm{L}, \mathrm{PCS}}$ and $A_{\mathrm{M}, \mathrm{PCS}}$ for all the PCS's containing different number of $\mathrm{N}$ atoms, as previously described. ${ }^{17}$

Protein abundance-Protein abundance was estimated by the XIC intensity of a protein which was the sum of XIC intensities from all detected PCS's for the protein. This is analogous to the spectral counting (SC) method in which protein abundance is measured by the total MS2 spectral counts for all detected peptides belonging to a protein. The SC method was originally conceived based on the hypothesis that "the more abundant a peptide ion is in a mixture, the higher the rate of sampling during the course of a shotgun proteomics experiment." ${ }^{27} \mathrm{SC}$ has become an accepted method for label-free quantitation in proteomics, ${ }^{28}$ compared favorably to measurements of XIC intensities, ${ }^{29}$ and shown to bear quantitative characteristics similar to gene data in transcriptomics. ${ }^{30}$ Therefore, it was also reasonable to expect that the XIC intensity of a protein correlates positively with protein abundance.

Meanwhile, we caution that this method be treated conservatively only as a means to detect difference rather than to obtain protein absolute abundance. This is because we did not calibrate the linear response of the peptide or protein XIC intensities with the actual protein moles in the samples throughout the whole dynamic range, which is out of the scope of this work. The same caution is applied to the protein relative abundance estimated from the ratio of protein XIC intensities as described below. Such precaution has been raised by others. ${ }^{31}$

Protein abundance was measured in three forms, namely $A_{\mathrm{L}}, A_{\mathrm{M}}$ and $A_{\mathrm{T}}$. $A_{\mathrm{L}}$ represents the XIC intensity of the fraction of a protein being carried over from the late-log-phase cells and surviving degradation/secretion after the cells were resuspended into the fresh $\left[{ }^{15} \mathrm{~N}\right]$ labeled media. $A_{\mathrm{M}}$ represents the XIC intensity of the fraction synthesized after the late-log-phase cells were resuspended into the fresh $\left[{ }^{15} \mathrm{~N}\right]$ labeled media. $A_{\mathrm{T}}$ represents the total XIC intensity of a protein which is the sum of $A_{\mathrm{L}}$ and $A_{\mathrm{M}} . A_{\mathrm{L}}$ is the sum of $A_{\mathrm{L}, \mathrm{PCS}}$ from all the PCS's belong to the same protein. Similarly, $A_{\mathrm{M}}$ is the sum of $A_{\mathrm{M}, \mathrm{PCS}}$ from all the PCS's belong to that protein. Each of $A_{\mathrm{L}}, A_{\mathrm{M}}$ and $A_{\mathrm{T}}$ of a protein was normalized by the sum of $A_{\mathrm{T}}$ of all proteins quantified from an injection, so that it could be compared among different injections regardless whether the injections were from the same or a different sample.

Protein relative abundance-Protein relative abundance was estimated by the ratio of XIC intensities of a protein in the HI cells versus the LI cells, determined for each of $A_{\mathrm{L}}, A_{\mathrm{M}}$ and $A_{\mathrm{T}}$. Accordingly, protein relative abundance also has the three corresponding forms, namely $R A_{\mathrm{L}}, R A_{\mathrm{M}}$ and $R A_{\mathrm{T}}$. For example, $R A_{\mathrm{L}}$ is the $A_{\mathrm{L}}$ ratio of the $\mathrm{HI}$ over the LI sample. Since the HI and LI samples were each analyzed in triplicate injections, we define triplicate for each of $R A_{\mathrm{L}}, R A_{\mathrm{M}}$ and $R A_{\mathrm{T}}$ as well. $R A_{\mathrm{T}, 1}$ is the $A_{\mathrm{T}}$ ratio between HI-Inj1 and LI-Inj1. $R A_{\mathrm{T}, 2}$ is the $A_{\mathrm{T}}$ ratio between HI-Inj2 and LI-Inj2. $R A_{\mathrm{T}, 3}$ is the $A_{\mathrm{T}}$ ratio between HI-Inj3 and LI-Inj3. $R A_{\mathrm{L}, 1}, R A_{\mathrm{L}, 2}, R A_{\mathrm{L}, 3}, R A_{\mathrm{M}, 1}, R A_{\mathrm{M}, 2}$, and $R A_{\mathrm{M}, 3}$ are defined according to the same paring of injections as for $R A_{\mathrm{T}, 1}, R A_{\mathrm{T}, 2}$ and $R A_{\mathrm{T}, 3}$.

Protein turnover-Protein turnover is the protein synthesis over degradation ratio (S/D) as defined by Cargile et al ${ }^{32}$ and utilized previously. ${ }^{17}$ Here, $\mathrm{S} / \mathrm{D}$ is the ratio of $A_{\mathrm{M}}$ over $A_{\mathrm{L}}$.

Label-free quantitation of $\boldsymbol{A}_{\mathbf{L}}, \boldsymbol{A}_{\mathbf{M}}$ and $\boldsymbol{A}_{\mathbf{T}}$-In order to compare the $A_{\mathrm{L}}, A_{\mathrm{M}}$ and $A_{\mathrm{T}}$ levels between the $\mathrm{HI}$ and LI cells, we needed to compute the normalized $A_{\mathrm{L}}, A_{\mathrm{M}}$ and $A_{\mathrm{T}}$ levels in the HI and LI cells respectively. Here, the term 'label-free quantitation' refers to the method of quantifying relative abundance of a protein between two samples of the same isotopic composition, ${ }^{18,19,33,34}$ rather than to the isotopic composition of the cell proteins. Although the H37Rv cells were partially $\left[{ }^{15} \mathrm{~N}\right]$ labeled, quantification of $A_{\mathrm{L}}$, e.g., between the HI and LI cells required the same label-free quantitation approach for two samples with the same isotopic 
composition. ${ }^{18}, 19,33,34$ This was also applicable to the comparison of $A_{\mathrm{M}}$ and $A_{\mathrm{T}}$ between the $\mathrm{HI}$ and LI cells.

To perform the label-free analysis, we first aligned the base peak intensity (BPI) chromatograms ${ }^{19}$ of two injections, as illustrated in Figure 2. One injection (LI-Inj1) was designated as the 'raw trace' from which $A_{\mathrm{L}, \mathrm{PCS}}$, and $A_{\mathrm{M}, \mathrm{PCS}}$ were calculated. The other injection (HI-Inj1) was designated as the 'pair trace' from which the PCS's to be quantified were assigned based on database search result for HI-Inj1. For alignment, the blue PCS markers shown in Figure 2 were used for determining the fitting functions of linear compression or extension. ${ }^{18}$ The fitting functions were then used to align the HI-Inj1 trace against the LI-Inj1 trace. The red PCS markers represent the PCS markers after the time normalization (see Figure 2 caption for more details). The alignment allowed quantitation of a PCS identified by MS/MS in HI-Inj1 but not in LI-Inj1. Similar label-free quantitation methodologies have already been well documented by many others. ${ }^{18,19,33,34}$

With LI-Inj1 designated as the raw trace, the above approach was repeated for the other five pair traces including LI-Inj1 itself (Figure S2, SI). Therefore, every PCS identified in one or more of the six pair injections was interrogated against the raw file of LI-Inj1 for quantitation of $A_{\mathrm{L}, \mathrm{PCS}}$ and $A_{\mathrm{M}, \mathrm{PCS}}$. Each PCS was integrated over a 1.5 min elution time window in the LIInj1 raw trace, with a mass tolerance of $10 \mathrm{ppm}$. After all the PCS's were determined for $A_{\mathrm{L}, \mathrm{PCS}}$ and $A_{\mathrm{M}, \mathrm{PCS}}$ from LI-Inj1, the quantified PCS's were combined. Duplicate measurements of a PCS were screened for outliers by the Dixon's Q-test (95\% confidence level) and averaged. The PCS's belonging to the same protein were grouped, and their $A_{\mathrm{L}, \mathrm{PCS}}$ and $A_{\mathrm{M}, \mathrm{PCS}}$ values were summed respectively. The summed $A_{\mathrm{L}, \mathrm{PCS}}$ and $A_{\mathrm{M}, \mathrm{PCS}}$ from all the PCS's of a proteins became $A_{\mathrm{L}}$ and $A_{\mathrm{M}}$ of that protein. The sum of $A_{\mathrm{L}}$ and $A_{\mathrm{M}}$ represents the protein XIC intensity $A_{\mathrm{T}}$. Finally, $A_{\mathrm{L}}, A_{\mathrm{M}}$, and $\mathrm{AT}$ of each protein quantified in LI-Inj1 were normalized by the sum of $A_{\mathrm{T}}$ from all the proteins quantified in LI-Inj1.

The above procedure was repeated for each of the remaining five raw traces. Total 36 pairs of raw trace-pair trace alignment were done, including the six shown in Figure S1. Total six tables containing the $A_{\mathrm{L}}, A_{\mathrm{M}}$, and $A_{\mathrm{T}}$ values for each protein were generated, with one table for each injection. Accepted for further interpretation were only the 104 proteins with no more than one missing value of either $A_{\mathrm{L}}$ or $A_{\mathrm{M}}$ in all the six injections.

After the above normalization and peptide cross-reference procedure, each protein had exactly the same set of PCS's which XIC intensities were summed to generate the protein XIC intensity. This improved the comparability of the protein abundance between the HI and LI experimental conditions and among the different isotopic forms of the protein. Linear response of peptide XIC intensities to protein quantities has been demonstrated. ${ }^{29}, 34$ It was observed that nearly all peptides from the standards spiked into a complex sample showed linearity between XIC intensity and protein amounts. ${ }^{29}$ Linear regression analysis of XIC intensity and protein quantity revealed that all peptides from a mixture of protein standards showed similar slopes even though the LOD for individual peptides varied. ${ }^{35}$ Since each protein we compared between samples or isotopic forms shared the same set of PCS's, linear combination (including summation) of the PCS XIC intensities should represent a vector which magnitude is proportional to the protein quantity. For these reasons, we used the protein XIC intensity as a relative estimation of the protein abundance between the $\mathrm{HI}$ and LI conditions and among the different isotopic forms. Based on the similar principle of the SC method, ${ }^{27}$ the protein XIC intensity was also used as a qualitative or semi-quantitative indicator of the abundance of a protein within a sample. More quantitative study of this method throughout the whole dynamic range of the nanoLC/LTQ-FT instrument is out of the scope of this work and will be pursued in future work. 


\section{RESULTS AND DISCUSION}

We are interested in deciphering the response of the M. tuberculosis $\mathrm{H} 37 \mathrm{Rv}$ proteome to a change in iron level by monitoring both the protein abundance and turnover. Conventionally, protein relative abundance between two samples provides a snapshot of the comparative proteome composition of the cells at two different states. The dynamic process leading to this end-point state, however, can not be readily deduced from relative abundance measurement alone. ${ }^{22}$ Our previous study of global protein turnover for stressed $M$. smegmatis cells ${ }^{17}$ reveals some interesting proteome dynamic response. But the picture was not complete without the protein abundance information.

In this work, we are able to obtain both the protein abundance and turnover values to more comprehensively assess the response of the iron-starved late-log-phase H37Rv cells to the fresh $\mathrm{HI}$ and LI media. This is achieved by several techniques including protein absolute ${ }^{18,19}$ and relative $^{20,21}$ abundance measurement, protein turnover analysis, ${ }^{17,} 22$ and cluster analysis. ${ }^{23}$, ${ }^{24}$ Altogether, 104 proteins are quantified for both protein abundance and turnover in both the $\mathrm{HI}$ and LI cells, with triplicate measurements for each value.

\section{Protein abundance and turnover}

We first compare the protein relative abundance between the HI and LI samples. Figure 3 shows the M-A plot of $A_{\mathrm{T}}$ for the 104 proteins between the HI and LI samples. The $x$-axis represents the square root of the product of the average $A_{\mathrm{T}}$ of a protein in the HI sample and the LI sample. The $y$-axis represents the ratio of average $A_{\mathrm{T}}$ between the HI and the LI samples.

Immediately apparent is that a dynamic range of 4-order in protein XIC intensity measurement was achieved. This is consistent with the large dynamic range of 4-order magnitude reported for XIC intensity measurements with a single dimension of LC separation using a LTQOrbitrap mass spectrometer. ${ }^{31}$ The right-most 3 proteins on the A scale, namely GroEL2 (Rv0440), GroES (Rv3418c), and MIHF (Rv1388), have an average $A_{\mathrm{T}}$ of $0.29,0.12$, and 0.05 respectively in the LI sample, and $0.25,0.09$, and 0.06 respectively in the HI sample. The total XIC intensities of these 3 proteins occupy $46 \%$ and $40 \%$ of the total detected protein XIC intensities in the LI and $\mathrm{HI}$ samples respectively. On the contrary, the left-most 3 proteins on the A scale, namely Rv1201c, Rv2606c, and ModD (Rv1860), have an average $A_{\mathrm{T}}$ of $1.0 \times 10^{-4}, 4.4 \times 10^{-5}$, and $4.5 \times 10^{-5}$ respectively in the LI sample, and $3.7 \times 10^{-5}, 5.1 \times 10^{-5}$, and $5.5 \times 10^{-6}$ respectively in the HI sample. The combined XIC intensities of these 3 proteins occupy only $0.02 \%$ and $0.009 \%$ of the total detected protein XIC intensities in the LI and HI samples respectively. We quantified 104 proteins using the 1D-nanoLC/MS approach reported here. When the complexity of the protein mixtures is further reduced by fractionation, we anticipate that more proteins should be quantified in future studies. The dominant XIC intensity of GroEL2 suggested its high abundance in the samples which was consistent with the stressful conditions under which these cells were grown.

Upon dilution of the late-log-phase LI cells into fresh HI medium in comparison to fresh LI medium, only 5 proteins were upregulated $(p<0.05)$ while 16 were downregulated $(p<0.05)$. The $p$ is the probability of a two-tailed homoscedastic Student's $t$-test performed on the triplicate $A_{\mathrm{T}}$ values of the HI and LI samples.

Among the 104 proteins (Figure 3), only the genes of PpiA (Rv0009), KatG (Rv1908c) and $\mathrm{Rv} 0284$ were among those found regulated by iron in previous microarray analysis. ${ }^{10} \mathrm{PpiA}$, KatG and Rv0284 ranked $19^{\text {th }}, 43^{\text {rd }}$ and $97^{\text {th }}$ in average protein XIC intensity among the 104 proteins. This suggests that many iron regulated proteins including those involved in siderophore synthesis may be at lower abundance and have not been detected in this study. Future more in-depth proteome analysis will be necessary to cover these proteins. Nevertheless, 
the changes in protein abundance for PpiA, KatG and Rv0284 are similar to the changes in gene expression determined in previous microarray study. ${ }^{10} \mathrm{PpiA}, \mathrm{KatG}$ and Rv0284 have a protein abundance ratio of $1.90(p=0.0004), 1.28(p=0.1)$ and $0.06(p=0.007)$ respectively in the HI versus LI sample. The genes of PpiA and KatG were induced by HI by $2.7 \pm 0.1$ and $1.7 \pm 0.2$ respectively, and that of Rv0284 was induced by LI by $4.1 \pm 0.2{ }^{10}$

We further examine the MA plots between $A_{\mathrm{L}}$ and $A_{\mathrm{M}}$ for the 104 proteins in the HI and LI cells respectively (Figure 4 ). As defined previously, $A_{\mathrm{L}}$ represents the XIC intensity of the old fraction of a protein and $A_{\mathrm{M}}$ represents the de novo synthesized fraction of a protein. The $\mathrm{M}$ scale of $A_{\mathrm{M}} / A_{\mathrm{L}}$ is equivalent to the protein synthesis over degradation ratio (S/D). ${ }^{17,} 32$ Comparing the two panels in Figure 4 reveals that there was apparently more active protein synthesis activity in the HI than in the LI cells. In the LI cells, there were 24 proteins with significant S/D increase (2-fold with $p<0.05$ ) and 8 with significant S/D decrease. In the HI cells, on the other hand, 56 proteins had significant S/D increase while only 5 proteins had significant S/D decrease. Compared to the results in Figure 3 with protein relative abundance measurement alone, the S/D measurement results summarized in Figure 4 more strongly support that iron is critical for protein synthesis and cell growth.

\section{Cluster analysis}

The above results are further analyzed using the hierarchical clustering program by Eisen et al. ${ }^{23}$ The clustering results were visualized by Eisen's TreeView program. These two programs were originally developed for and have been widely used in microarray data analysis. As demonstrated in microarray analysis, ${ }^{24}$ we anticipated that the cluster analysis would allow us to systematically explore the internal correlation of the protein abundance and turnover data in the HI and LI cells, which has been difficult to solve by simple correlation and fold change methods used previously. ${ }^{17}$ The cluster analysis reveals the trend of change for groups of proteins. The following described changes or differences among protein groups are mostly based on visual inspection of the TreeView image and do not infer statistical testing.

Figure 5 shows the cluster analysis using the $R A_{\mathrm{T}}, R A_{\mathrm{L}}$, and $R A_{\mathrm{M}}$ triplicate values. Displayed also is the ratio of $\mathrm{S} / \mathrm{D}$ between the HI and LI samples, which is not included for clustering. From the left to the right, the four image strips represent $R A_{\mathrm{T}}, R A_{\mathrm{L}}, R A_{\mathrm{M}}$, and $R_{\mathrm{S} / \mathrm{D}}$ respectively. In each image strip, triplicate measurement values are presented for each protein. Shown next to the $R_{\mathrm{S} / \mathrm{D}}$ strip are the protein names. For simplicity, a protein name is represented by its gene symbol or by its open reading frame (ORF) when a protein is hypothetical. For each protein, the square cells in the image strips graphically represent the log transformed values of $R A_{\mathrm{T}}$, $R A_{\mathrm{L}}, R A_{\mathrm{M}}$, or $R_{\mathrm{S} / \mathrm{D}}$. According to the convention, ${ }^{23}$ cells with 0 (ratios of $1-$ unchanged in $A_{\mathrm{T}}, A_{\mathrm{L}}, A_{\mathrm{M}}$, or $\mathrm{S} / \mathrm{D}$ ) are colored black, increasingly positive log ratios are colored with reds of increasing intensity, and increasingly negative log ratios are colored with greens of increasing intensity. Missing values are colored gray. To the left of the figure is the dendrogram indicating the nature of the correlation among the 104 proteins based on their $R A_{\mathrm{S}}, R A_{\mathrm{L}}$ and $R A_{\mathrm{M}}$ values.

In the dendrogram, three nodes (labeled I, II, and III) include 101 of the 104 proteins. Node I has a correlation coefficient of 0.46 and includes the proteins with increase in $A_{\mathrm{T}}, A_{\mathrm{M}}$, and $\mathrm{S} /$ $\mathrm{D}$ and mild change in $A_{\mathrm{L}}$. These proteins are designated to Zone 1 as indicated to the far right in the figure. Node II has a correlation coefficient of 0.77 and includes the proteins with decrease in $A_{\mathrm{T}}, A_{\mathrm{L}}$ and $A_{\mathrm{M}}$ and various changes in $\mathrm{S} / \mathrm{D}$. These proteins are designated to Zone 2. Node III has a correlation coefficient of 0.64 and includes the proteins with mild change in $A_{\mathrm{T}}$, decrease in $A_{\mathrm{L}}$, and increase in $A_{\mathrm{M}}$ and S/D. These proteins are designated to Zone 3 . KasB ( Rv2246) is a free protein between Zone 1 and 2. RplQ (Rv3456c) and Rv2520c are two proteins clustered together at the bottom of the image strips that appear to have large measurement variations. The node joining these two proteins has a correlation coefficient less than 0.28 with Node I, II, and III. 
The proteins in Zone 1 increase in $A_{\mathrm{T}}$. These proteins have mild changes in $A_{\mathrm{L}}$, suggesting degradation is minimal for these proteins. The change in $A_{\mathrm{T}}$ is mostly attributed to the increase in $A_{\mathrm{M}}$, i.e. upregulation in de novo protein synthesis in the $\mathrm{HI}$ cells. This upregulation of de novo protein synthesis is also reflected by the increase of S/D in the HI cells.

The proteins in Zone 2 are downregulated. The $A_{\mathrm{L}}$ values of these proteins decrease as well, suggesting that protein degradation contributes to the downregulation in $A_{\mathrm{T}}$. Zone 2 has two major clusters, as indicated by the red and black bars.

The cluster indicated by the red bar in Zone 2 contains 14 proteins. These proteins increase in $\mathrm{S} / \mathrm{D}$, as shown by the red cells in the $4^{\text {th }}$ image strip, but downregulated in protein abundance. It is possible that protein de novo synthesis increases for these proteins in the HI cells. But the increase is not sufficient to compensate for the decrease in $A_{\mathrm{T}}$ due to more prominent protein degradation or secretion. Another possibility is that protein degradation or secretion is accelerated in the HI cells for these proteins. Even if protein de novo synthesis remains the same, additional protein degradation or secretion would further increase the $S / D$, as previously discussed. ${ }^{17}$ Given that $R A_{\mathrm{L}}$ is negative for these proteins as shown by the $2^{\text {nd }}$ image strip in Figure 5, the later mechanism is more plausible.

The second major cluster in Zone 2, as indicated by the black bar in Figure 5, contains 15 proteins. These proteins approximately have no change in S/D, suggesting that decrease in protein abundance is mostly due to protein degradation or secretion. Interestingly, four chaperones/chaperonins are closely clustered in this group, including DnaK, GroEL1, GroEL2, and GroES. This supports the validity of the clustering method.

The proteins in Zone 3 have mild changes in $A_{\mathrm{T}}$. The interesting feature of this zone is that these proteins decrease in $A_{\mathrm{L}}$ but increase in $A_{\mathrm{M}}$, indicating increased activity in both protein degradation/secretion and protein de novo synthesis in the HI cells. This leads to high protein turnover as shown by the intense reds in the cells of the $4^{\text {th }}$ image strip. The rates of protein degradation and synthesis are approximately the same, leading to nominal change in $A_{\mathrm{T}}$.

As shown above, the clustering analysis reveals dynamic interplay of protein synthesis, degradation, and secretion that jointly decide the net abundance of a protein in a living cell. Combined analysis of mRNA transcript level, protein abundance, and protein turnover will very likely further our understanding of the concerted action among the transcription, translation, degradation, and secretion machineries that governs the complex intra- and extracellular processes in M. tuberculosis. Many studies on both transcriptome and proteome profiles revealed moderate to low correlation between the two. ${ }^{21,} 36-38$ We anticipate that the combined analysis will in the future help elucidate the mechanisms behind the discrepancy between transcriptome and proteome profiles and its implication in cell biology.

\section{Functional analysis}

Table 1 summarizes the 26 proteins that have greater than 2 -fold change $(p<0.05)$ in S/D, with 10 in Zone 1, 12 in Zone 3, 3 in Zone 2, and 1 as a free protein. The functional category classification is based on Tuberculist ${ }^{39}$ for most of the proteins except that several are updated with annotation information from TB SGC. ${ }^{40}$

In Table 1, there are 8 ribosomal proteins in Zone 1, all of which have apparent trend of increase in relative abundance. These ribosomal proteins are known to be functionally related, supporting the cluster analysis method used in Figure 5. RpsD and RplL are abundant proteins present in the cells, as indicated by the about 3\% XIC intensity contributed by these two proteins. The results of the ribosomal proteins clearly indicate that high iron level induces more vigorous protein synthesis. 
The 12 proteins in Zone 3 have more diverse functions than those in Zone 1.

The homologues of KatG, AtpD, and SodA in M. smegmatis were previously found to have lower S/D when M. smegmatis was shifted from HI to LI media. ${ }^{17}$ The results we obtain here with $M$.tuberculosis confirm what we found previously. KatG and SodA are key members of the mycobacterial reactive oxidative species detoxification system ${ }^{41,42}$ having significant role in protecting $M$. tuberculosis against oxidative stress during host immune response to mycobacterial infection. Both enzymes use iron as a cofactor.

The average XIC intensity is $0.2 \%$ for $\mathrm{KatG}, 0.1 \%$ for SodA, and $0.4 \%$ for AtpD. Although S/ $\mathrm{D}$ significantly increases for these 3 proteins, their intracellular level does not increase significantly. This could be due to the secretion of these enzymes. KatG, AtpD, and SodA were detected as exported proteins from the culture filtrate of H37Rv. ${ }^{43}$ Inadvertently, Sec (Rv0379) also has increased S/D, indicating that de novo syntheses of Sec is elevated in the HI cells. Sec is a possible protein transport protein, supporting that there may be accelerated secretion of $\mathrm{KatG}$, AtpD, and SodA.

Rv0315, FbpC2, and PhoS1 are predicted to be secreted proteins ${ }^{40}$ and indeed were found in the H37Rv culture filtrate. ${ }^{43}$ Rv0315 is a possible $\beta-1,3$-glucanase precursor. FbpC2 is a member of the mycobacterial antigen 85 complex which is a major secretion product of $M$. tuberculosis. ${ }^{44}$ Disruption of the antigen $85 \mathrm{~A}$ gene in this complex attenuated the virulence of $\mathrm{H} 37 \mathrm{Rv}$ in mice but the mutant retained vaccinogenic potential. ${ }^{45} \mathrm{PhoS} 1$ is the mycobacterial equivalent of the PstS component of phosphate uptake system, important for the phosphate uptake and virulence of M. tuberculosis. Disruption of the phoS1 gene in M. tuberculosis H37Rv reduced its virlulence. ${ }^{46}$

KasB is a free protein between Zones 1 and 2 in Figure 5. It is a 3-oxoacyl-(acyl carrier protein) synthase II involved in fatty acid and phospholipid metabolism. The mycobacterial kasAkas $B$ operon is required for mycolic acid synthesis, and is implicated in isoniazidsensitivity.

${ }^{47}$ It is striking to note that S/D is reduced by 5-fold in the HI cells. But its relative abundance remains largely unchanged. This could probably be explained by both decreased de novo synthesis and improved stability of KasB in the HI cells. This is supported by the observation (Figure 6) that $R A_{\mathrm{M}}$ is negative (green) while $R A_{\mathrm{L}}$ is positive (light red), leading to near-unity $R A_{\mathrm{T}}$ (near black) for KasB.

Rv0284 is a possible conserved membrane protein. Within Zone 2 in Figure 5, it is located in the smaller cluster indicated by the green bar. It decreases in all of the $A_{\mathrm{T}}, A_{\mathrm{L}}, A_{\mathrm{M}}$, and S/D values (Figure 6). Almost 10-fold decrease in S/D in combination with accelerated protein degradation leads to nearly 20 -fold decrease in relative abundance. There has not been evidence indicating that this hypothetical protein is secreted. Therefore, the result implies that Rv0284 is strongly repressed in the $\mathrm{HI}$ cells by both accelerated protein degradation and decrease in de novo synthesis. The downregulation of Rv0284 in total protein abundance is consistent with the previous microarray analysis showing that the Rv0284 gene was induced by LI. ${ }^{10}$

Rv0172 has more than 10-fold increase in S/D but decreases by 6-fold in total abundance $A_{\mathrm{T}}$. From Figure 6, it can be seen that Rv0172 is also repressed in $A_{\mathrm{L}}$, suggesting accelerated protein degradation in the HI cells. Comparison of $R A_{\mathrm{L}}$ and $R A \mathrm{M}$ indicates that $A_{\mathrm{M}}$ is reduced by a less extent than $A_{\mathrm{L}}$, consistent with the large increase in $\mathrm{S} / \mathrm{D}$. This supports that de novo protein synthesis for Rv0172 increases in the HI cells. We previously suggested that accelerated degradation increases S/D when de novo synthesis is upregulated. ${ }^{17}$ The result here again supports this notion. On the other hand, we can not rule out that protein secretion also plays a role similar to protein degradation in increasing S/D. We can not distinguish whether the increase in S/D is solely due to protein secretion or degradation, because both processes have the same effect on S/D. It is possible that both protein degradation and secretion play a role in 
increasing S/D and reducing total abundance of intracellular Rv0172. Future analysis of both intracellular and extracellular proteins will clarify this. Nevertheless, Rv0172 is predicted to be a secreted protein ${ }^{40}$ and indeed was found in the culture filtrate of H37Rv. ${ }^{43}$ It is thus very likely that Rv0172 is exported out of the HI cells. Rv0172 is a mammalian cell entrance protein involved in virulence of $M$. tuberculosis. It is reasonable to postulate that high-iron condition increases both de novo synthesis and secretion of Rv0172. Since de novo synthesis and secretion cancel out each other in regard to accumulation of intracellular protein abundance, the net result of increasing both de novo synthesis and secretion rates does not necessarily increase intracellular abundance of the protein, as evidenced in Figure 6. The experimental results support the postulation and is consistent with the fact that high iron load in host increases virulence of $M$. tuberculosis in vivo. ${ }^{48}$

The increased protein synthesis activity may contribute not only to the intracellular protein abundance but also to the cellular processes that facilitate protein secretion and modulation of extracellular matrix. The later activity enhances the virulence of $M$. tuberculosis. ${ }^{49}$ In addition, mycobacterial proteins that are exported into phagosomal compartment in vivo are likely to participate in remodeling of phagosomes. ${ }^{50}$ It would not be surprising if iron level modulates the ability of $M$. tuberculosis to synthesize and secrete proteins. The finding of which proteins are regulated by these processes is of paramount importance for understanding the virulence and intracellular survival of M. tuberculosis.

\section{CONCLUSION}

We have demonstrated simultaneous analysis of protein abundance and turnover when ironstarved M. tuberculosis $\mathrm{H} 37 \mathrm{Rv}$ cells were diluted in fresh $\mathrm{HI}$ medium. The results indicate that this approach uncover much more protein synthesis activities than it seems based on relative abundance measurement alone. The multi-dimensional information also facilitates cluster analysis of interconnection among protein synthesis, degradation, and secretion processes undergoing in the cells.

The approach we demonstrate here has several implications. First, it would be suitable for studying the protein dynamics in dormant mycobacterial cells that may not have apparent cell growth and changes in protein abundance. Second, it may be a sensitive method to monitor the protein synthesis activity and stability in mycobacterial cells undergoing antibiotic treatment. Given that many antibiotics target mycobacteiral transcription and translation machineries, this approach is useful for interrogating the effectiveness of these antibiotics in inhibiting the protein synthesis and the drug-resistance mechanisms behind. Third, the approach may also be useful for studying mycobacterium-macrophage interaction. Protein secretion is a major pathway for M. tuberculosis to modulate the host cells for its advantage. We have demonstrated that this approach is capable of monitoring protein synthesis, degradation, and secretion of the mycobacterial cells. In our ongoing work, we will continue to improve this method for studying the mycobacterial proteome dynamics within macrophages.

This method can be further extended to cover the mycobacterial proteome in more depth by reducing protein mixture complexity with multi-dimensional separation, as demonstrated by many studies in the field. With multi-dimensional information obtained by this method, indepth coverage of the mycobacterial proteome will likely lead to interesting insight into the iron metabolism and the pathogenesis of M. tuberculosis in general.

\section{Supplementary Material}

Refer to Web version on PubMed Central for supplementary material. 


\section{Acknowledgments}

This work was supported in part by the Hans Vahlteich Research Award to Q.L. from College of Pharmacy at University of Illinois at Chicago.

\section{REFERENCES}

1. Gold B, Rodriguez GM, Marras SA, Pentecost M, Smith I. Mol Microbiol 2001;42:851-865. [PubMed: 11722747]

2. Neilands JB. J Biol Chem 1995;270:26723-26726. [PubMed: 7592901]

3. Rodriguez GM, Smith I. Mol Microbiol 2003;47:1485-1494. [PubMed: 12622807]

4. Ratledge C. Tuberculosis (Edinb) 2004;84:110-130. [PubMed: 14670352]

5. Chandra RK. Bull World Health Organ 1979;57:167-177. [PubMed: 108017]

6. Gomes MS, Boelaert JR, Appelberg R. J Clin Virol 2001;20:117-122. [PubMed: 11166658]

7. Monfeli RR, Beeson C. Infect Disord Drug Targets 2007;7:213-220. [PubMed: 17897057]

8. Murillo AC, Li HY, Alber T, Baker EN, Berger JM, Cherney LT, Cherney MM, Cho YS, Eisenberg D, Garen CR, Goulding CW, Hung LW, Ioerger TR, Jacobs WR, James MN, Kim C, Krieger I, Lott JS, Sankaranarayanan R, Segelke BW, Terwilliger TC, Wang F, Wang S, Sacchettini JC. Infect Disord Drug Targets 2007;7:127-139. [PubMed: 17970224]

9. Ferreras JA, Ryu JS, Di Lello F, Tan DS, Quadri LE. Nat Chem Biol 2005;1:29-32. [PubMed: 16407990]

10. Rodriguez GM, Voskuil MI, Gold B, Schoolnik GK, Smith I. Infect Immun 2002;70:3371-3381. [PubMed: 12065475]

11. Waddell SJ, Butcher PD. Curr Mol Med 2007;7:287-296. [PubMed: 17504113]

12. Bacon J, Dover LG, Hatch KA, Zhang Y, Gomes JM, Kendall S, Wernisch L, Stoker NG, Butcher PD, Besra GS, Marsh PD. Microbiology 2007;153:1435-1444. [PubMed: 17464057]

13. Larrabee KL, Phillips JO, Williams GJ, Larrabee AR. J Biol Chem 1980;255:4125-4130. [PubMed: 6989832]

14. Prakash P, Yellaboina S, Ranjan A, Hasnain SE. Bioinformatics 2005;21:2161-2166. [PubMed: 15746274]

15. Bacon J, Marsh PD. Curr Mol Med 2007;7:277-286. [PubMed: 17504112]

16. Wong DK, Lee BY, Horwitz MA, Gibson BW. Infect Immun 1999;67:327-336. [PubMed: 9864233]

17. Rao PK, Roxas BA, Li Q. Anal Chem 2008;80:396-406. [PubMed: 18085750]

18. Andreev VP, Li L, Cao L, Gu Y, Rejtar T, Wu SL, Karger BL. J Proteome Res 2007;6:2186-2194. [PubMed: 17441747]

19. Fang R, Elias DA, Monroe ME, Shen Y, McIntosh M, Wang P, Goddard CD, Callister SJ, Moore RJ, Gorby YA, Adkins JN, Fredrickson JK, Lipton MS, Smith RD. Mol Cell Proteomics 2006;5:714725. [PubMed: 16401633]

20. Andreev VP, Li L, Rejtar T, Li Q, Ferry JG, Karger BL. J Proteome Res 2006;5:2039-2045. [PubMed: 16889428]

21. Li L, Li Q, Rohlin L, Kim U, Salmon K, Rejtar T, Gunsalus RP, Karger BL, Ferry JG. J Proteome Res 2007;6:759-771. [PubMed: 17269732]

22. Pratt JM, Petty J, Riba-Garcia I, Robertson DH, Gaskell SJ, Oliver SG, Beynon RJ. Mol Cell Proteomics 2002;1:579-591. [PubMed: 12376573]

23. Eisen MB, Spellman PT, Brown PO, Botstein D. Proc Natl Acad Sci U S A 1998;95:14863-14868. [PubMed: 9843981]

24. Fu LM, Fu-Liu CS. BMC Microbiol 2007;7:37. [PubMed: 17501996]

25. Zimmer JS, Monroe ME, Qian WJ, Smith RD. Mass Spectrom Rev 2006;25:450-482. [PubMed: 16429408]

26. Du X, Callister SJ, Manes NP, Adkins JN, Alexandridis RA, Zeng X, Roh JH, Smith WE, Donohue TJ, Kaplan S, Smith RD, Lipton MS. J Proteome Res. 2008

27. Liu H, Sadygov RG, Yates JR 3rd. Anal Chem 2004;76:4193-4201. [PubMed: 15253663] 
28. Mueller LN, Brusniak MY, Mani DR, Aebersold R. J Proteome Res 2008;7:51-61. [PubMed: 18173218]

29. Old WM, Meyer-Arendt K, Aveline-Wolf L, Pierce KG, Mendoza A, Sevinsky JR, Resing KA, Ahn NG. Mol Cell Proteomics 2005;4:1487-1502. [PubMed: 15979981]

30. Pavelka N, Fournier ML, Swanson SK, Pelizzola M, Ricciardi-Castagnoli P, Florens L, Washburn MP. Mol Cell Proteomics 2008;7:631-644. [PubMed: 18029349]

31. Finney GL, Blackler AR, Hoopmann MR, Canterbury JD, Wu CC, MacCoss MJ. Anal Chem 2008;80:961-971. [PubMed: 18189369]

32. Cargile BJ, Bundy JL, Grunden AM, Stephenson JL Jr. Anal Chem 2004;76:86-97. [PubMed: 14697036]

33. Hughes MA, Silva JC, Geromanos SJ, Townsend CA. J Proteome Res 2006;5:54-63. [PubMed: 16396495]

34. Wang G, Wu WW, Zeng W, Chou CL, Shen RF. J Proteome Res 2006;5:1214-1223. [PubMed: 16674111]

35. Zhu Z, Boobis AR, Edwards RJ. Proteomics 2008;8:1987-2005. [PubMed: 18491314]

36. Dihal AA, van der Woude H, Hendriksen PJ, Charif H, Dekker LJ, Ijsselstijn L, de Boer VC, Alink GM, Burgers PC, Rietjens IM, Woutersen RA, Stierum RH. Proteomics 2008;8:45-61. [PubMed: 18095365]

37. Nissom PM, Sanny A, Kok YJ, Hiang YT, Chuah SH, Shing TK, Lee YY, Wong KT, Hu WS, Sim MY, Philp R. Mol Biotechnol 2006;34:125-140. [PubMed: 17172658]

38. Xia Q, Hendrickson EL, Zhang Y, Wang T, Taub F, Moore BC, Porat I, Whitman WB, Hackett M, Leigh JA. Mol Cell Proteomics 2006;5:868-881. [PubMed: 16489187]

39. http://genolist.pasteur.fr/TubercuList/

40. http://www.doe-mbi.ucla.edu/TB/PUBLIC/

41. Milano A, Forti F, Sala C, Riccardi G, Ghisotti D. J Bacteriol 2001;183:6801-6806. [PubMed: 11698368]

42. Zahrt TC, Song J, Siple J, Deretic V. Mol Microbiol 2001;39:1174-1185. [PubMed: 11251835]

43. Malen H, Berven FS, Fladmark KE, Wiker HG. Proteomics 2007;7:1702-1718. [PubMed: 17443846]

44. Wiker HG, Harboe M. Microbiol Rev 1992;56:648-661. [PubMed: 1480113]

45. Copenhaver RH, Sepulveda E, Armitige LY, Actor JK, Wanger A, Norris SJ, Hunter RL, Jagannath C. Infect Immun 2004;72:7084-7095. [PubMed: 15557632]

46. Peirs P, Lefevre P, Boarbi S, Wang XM, Denis O, Braibant M, Pethe K, Locht C, Huygen K, Content J. Infect Immun 2005;73:1898-1902. [PubMed: 15731097]

47. Slayden RA, Barry CE 3rd. Tuberculosis (Edinb) 2002;82:149-160. [PubMed: 12464486]

48. Boelaert JR, Vandecasteele SJ, Appelberg R, Gordeuk VR. J Infect Dis 2007;195:1745-1753. [PubMed: 17492589]

49. Behr MA, Sherman DR. Nat Med 2007;13:286-287. [PubMed: 17342140]

50. Berthet FX, Lagranderie M, Gounon P, Laurent-Winter C, Ensergueix D, Chavarot P, Thouron F, Maranghi E, Pelicic V, Portnoi D, Marchal G, Gicquel B. Science 1998;282:759-762. [PubMed: 9784137] 

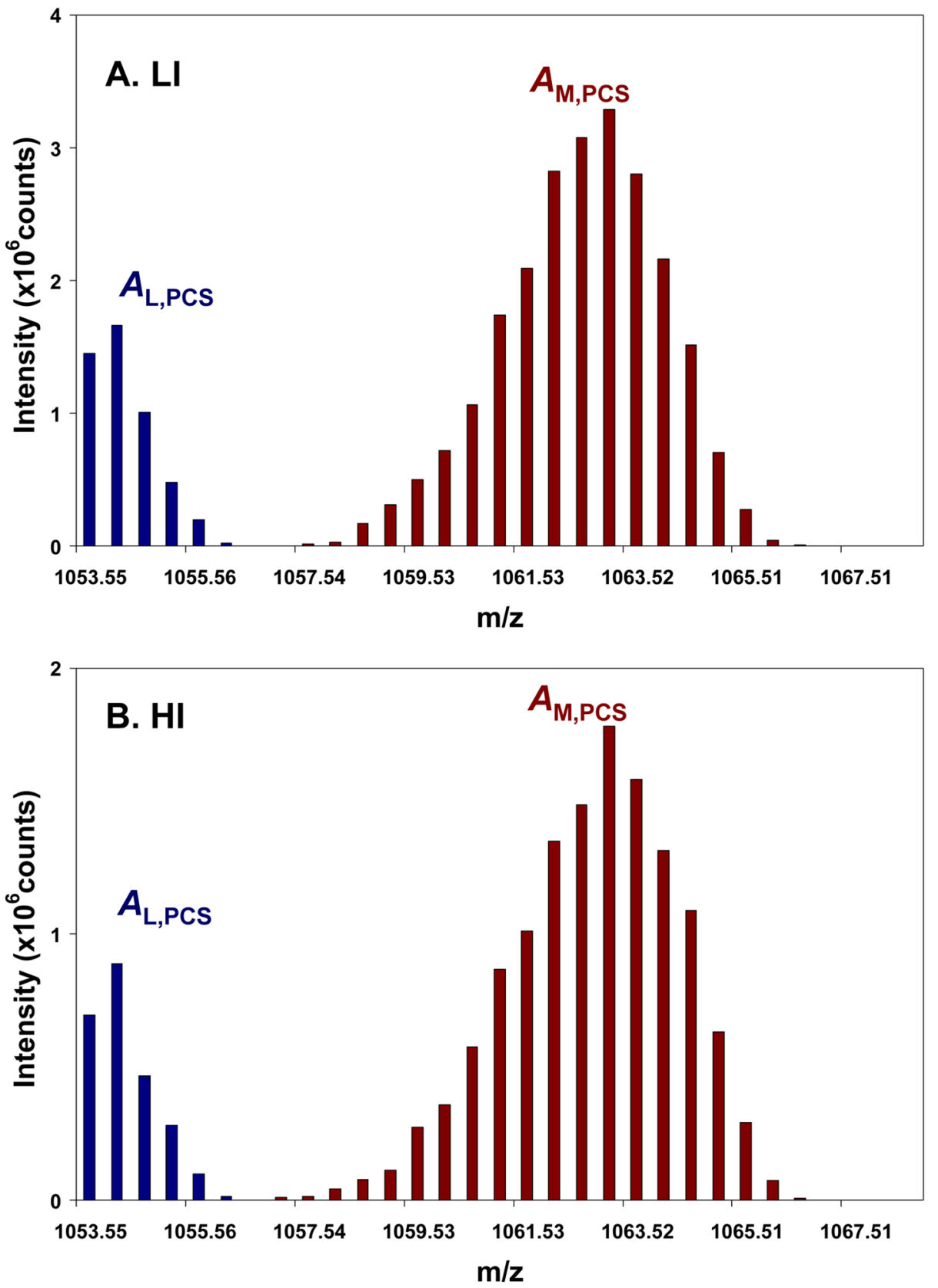

Figure 1.

The isotopologue profile of the tryptic PCS VQFQSGGANSPALYLLDGLR $\left(\mathrm{MH}_{2}{ }^{2+}, 26 \mathrm{~N}\right.$ atoms) of FbpA in the LI cells (A) and the HI cells (B). The dark blue isotopomer cluster represents the isotopologue originating from the $\left[{ }^{14} \mathrm{~N}\right]$ labeled fraction of FbpA which XIC intensity is represented by $A_{\mathrm{L}, \mathrm{PCS}}$. The dark red isotopomer cluster represents the isotopologue originating from the fraction of FbpA labeled by $\left[{ }^{15} \mathrm{~N}\right]$ which XIC intensity is represented by $A_{\mathrm{M}, \mathrm{PCS}}$. 


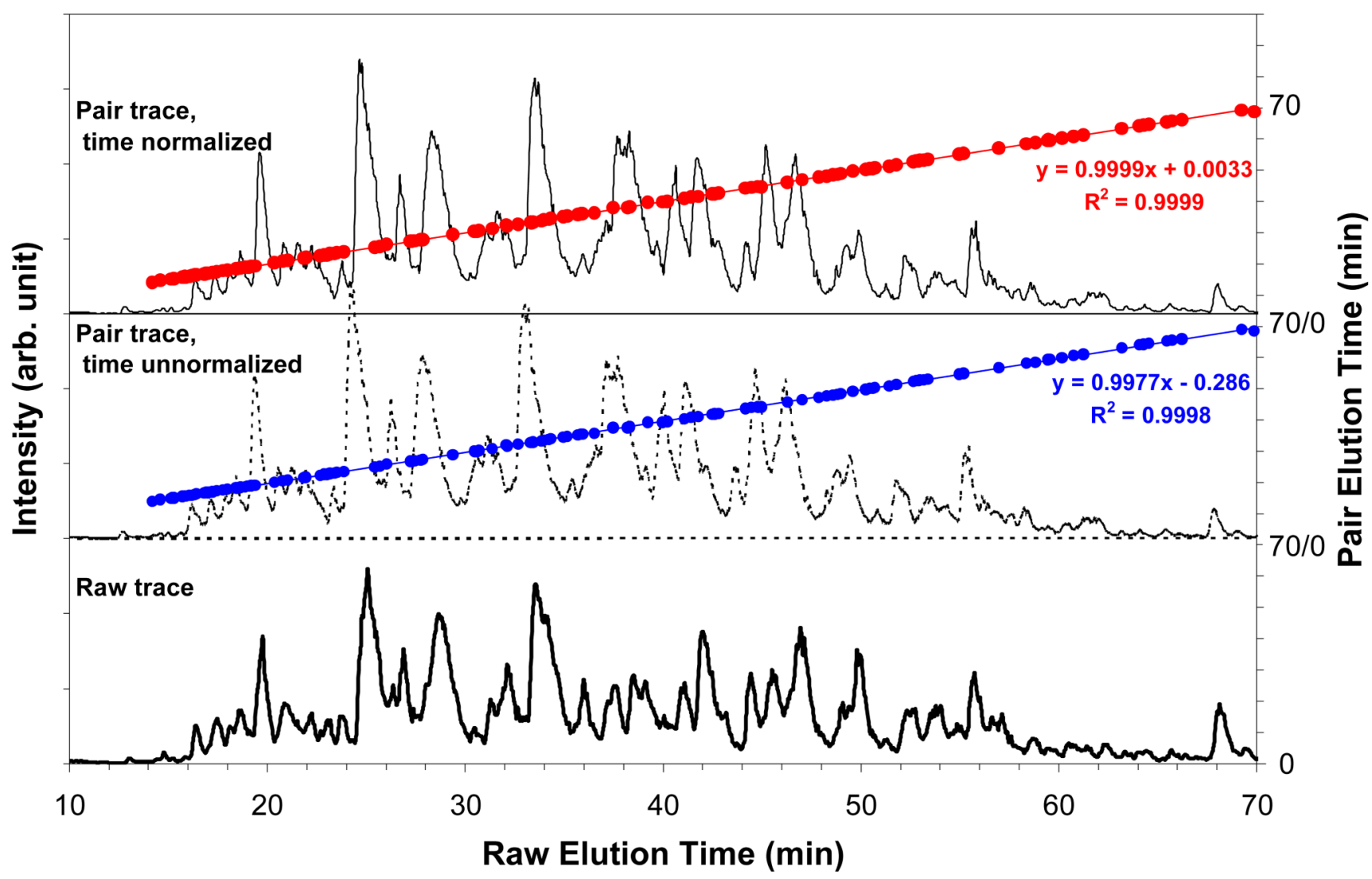

Figure 2.

BPI chromatogram alignment of the raw trace LI-Inj1 and the pair trace HI-Inj1. The bottom thick black line is the BPI chromatogram of LI-Inj1. The middle dash black line is the unnormalized BPI chromatogram of HI-Inj1. The top thin black line is the normalized BPI chromatogram of HI-Inj1. The primary $y$-axis (left) represents the intensity axis for the three stacked BPI chromatograms. The blue and red dots are the PCS markers found common between LI-Inj1 and HI-Inj1 before and after time normalization, respectively. The secondary $y$-axis (right) represents the elution time of these PCS markers in HI-Inj1, while the elution time of these markers in LI-Inj1 is represented by the $x$-axis. The linear trend lines running through the blue and red PCS markers and the equations displayed under them (to the right) indicate the goodness of the normalization and the extent of correction. 


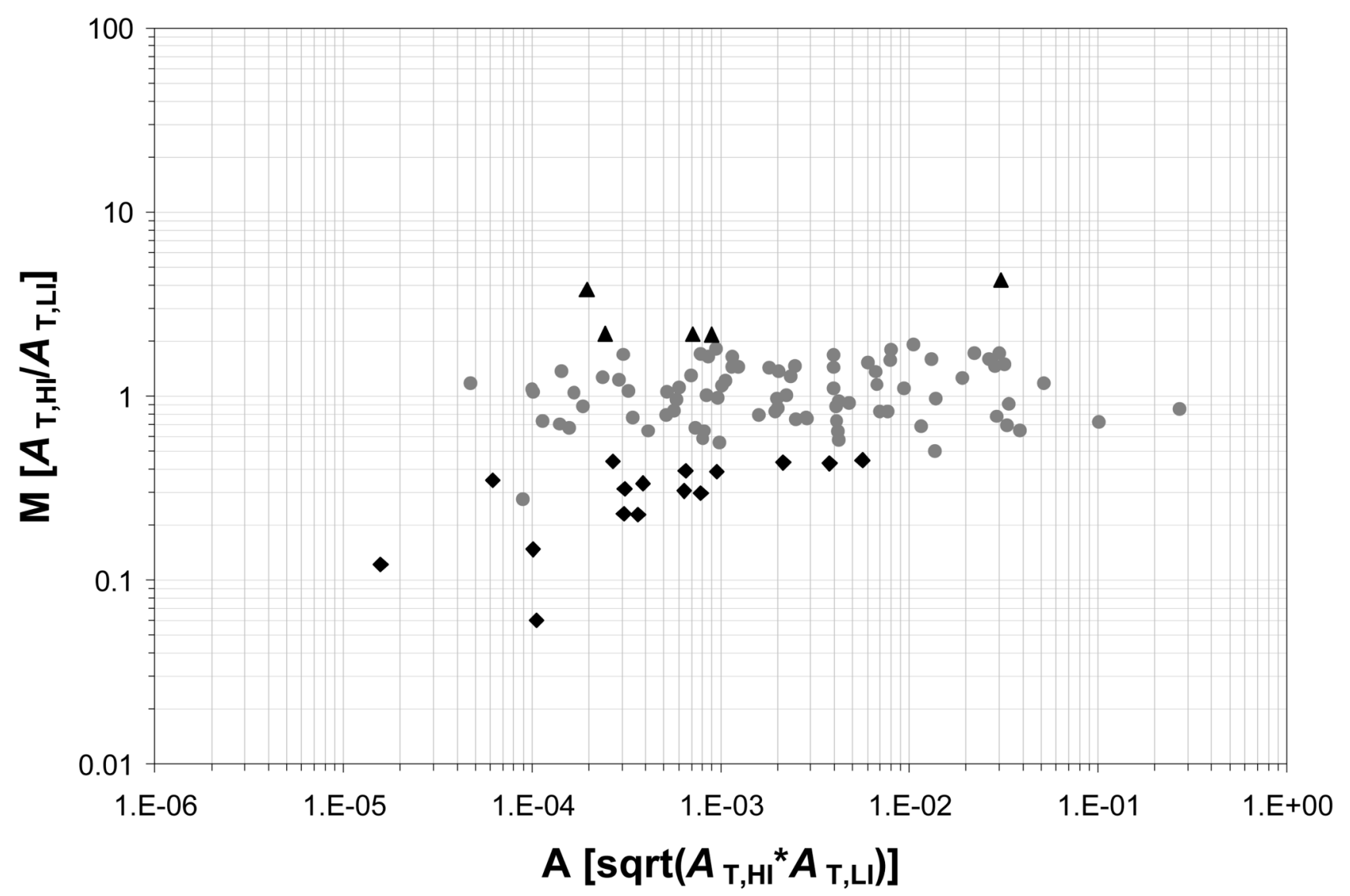

Figure 3.

MA plot of the protein XIC intensity $\left(A_{\mathrm{T}}\right)$ in the HI versus the LI cells. $A_{\mathrm{T}, \mathrm{HI}}, \mathrm{A}_{\mathrm{T}}$ in the HI cells. $A_{\mathrm{T}, \mathrm{LI}}, A_{\mathrm{T}}$ in the LI cells. $A_{\mathrm{T}, \mathrm{HI}} / A_{\mathrm{T}, \mathrm{LI}}$ beyond 2 -fold $(p<0.05)$ is considered a significant difference (black triangles and diamonds). $p$ is the Student's $t$-test probability based on the triplicate measurements for $A_{\mathrm{T}, \mathrm{HI}}$ and $A_{\mathrm{T}, \mathrm{LI}}$. 

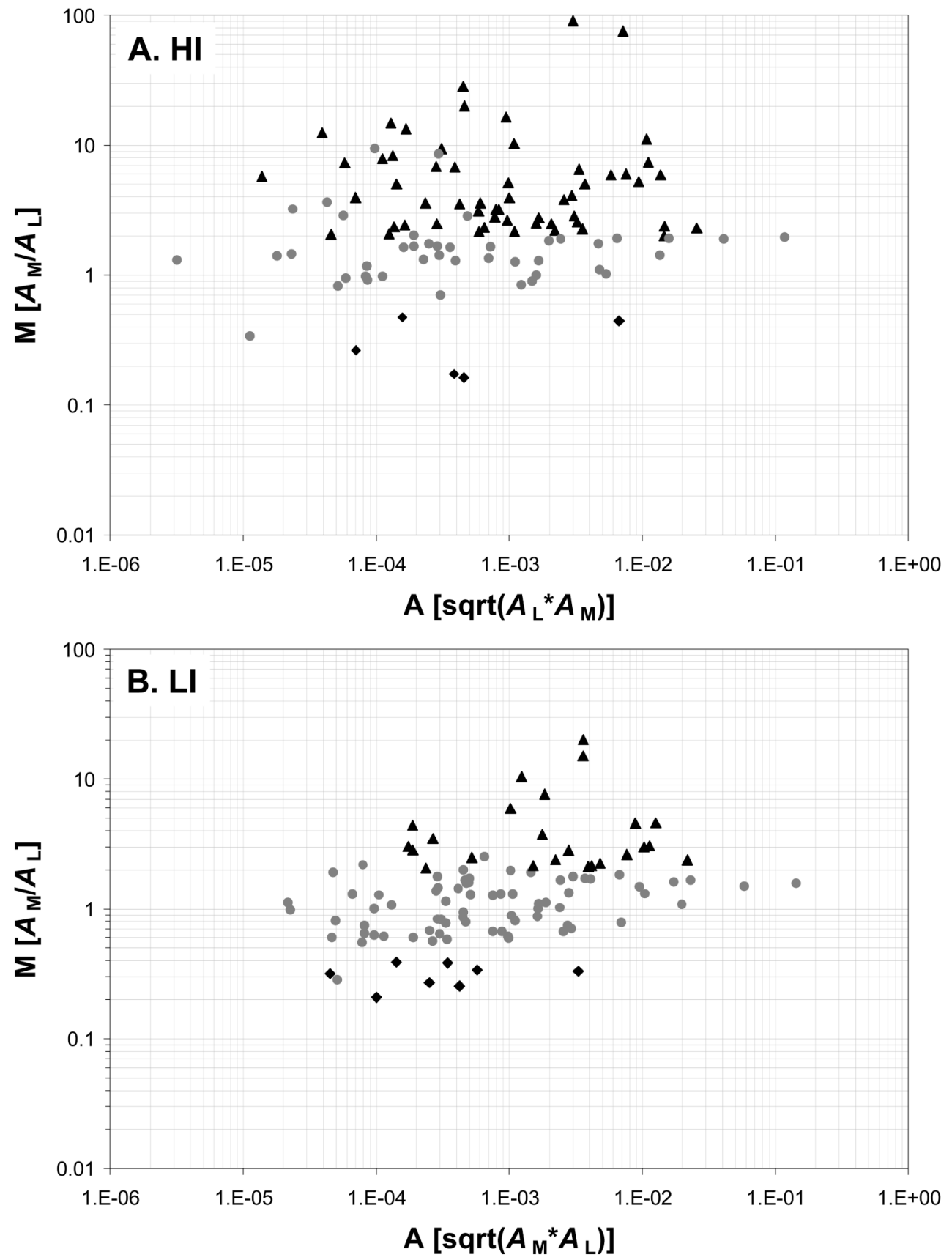

Figure 4.

MA plot of the average de novo synthesized protein XIC intensity $\left(A_{\mathrm{M}}\right)$ versus the average old protein XIC intensity $\left(A_{\mathrm{L}}\right)$ in the HI cells $(\mathrm{A})$ and the LI cells $(\mathrm{B}) . A_{\mathrm{M}} / A_{\mathrm{L}}$ beyond 2-fold ( $p$ $<0.05$ ) is considered a significant difference (black triangles and diamonds). $p$ is the Student's $t$-test probability based on the triplicate measurements for $A_{\mathrm{M}}$ and $A_{\mathrm{L}}$. 


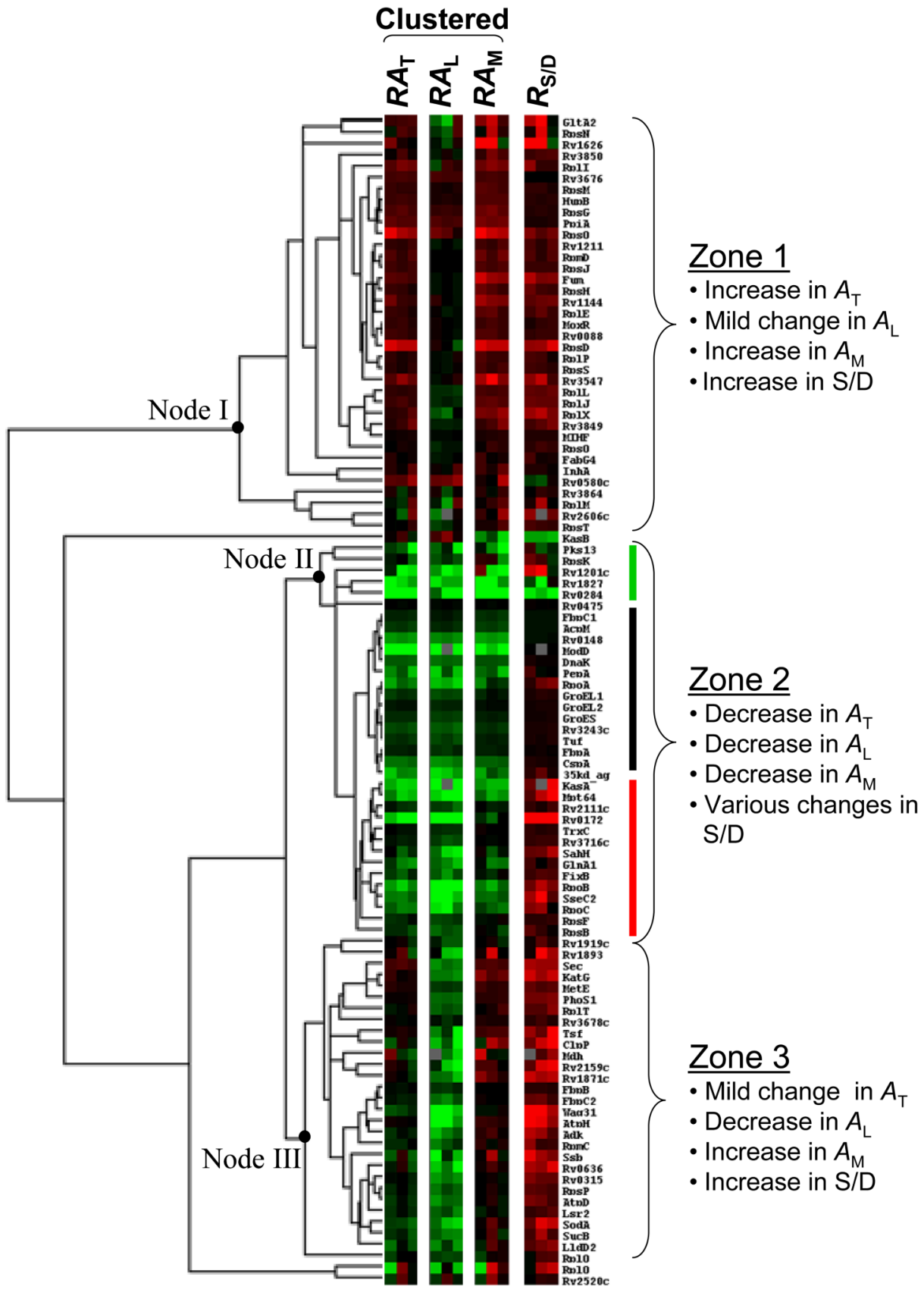

Figure 5.

Hierarchical cluster analysis using Eisen's CLUSTER program. See text for details. 

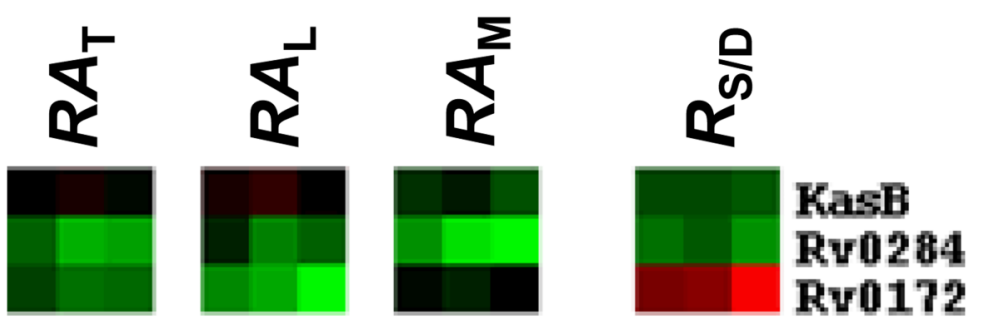

Figure 6.

Heat map of $R A_{\mathrm{T}}, R A_{\mathrm{L}}, R A_{\mathrm{M}}$, and $R_{\mathrm{S} / \mathrm{D}}$ for proteins KasB, Rv0284, and Rv0172. See text for more details. 


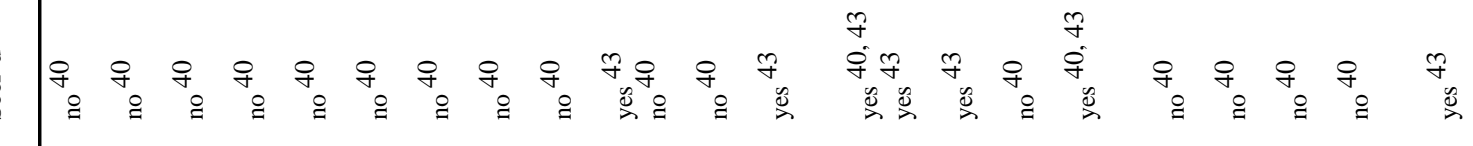

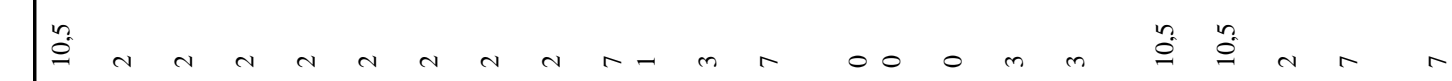

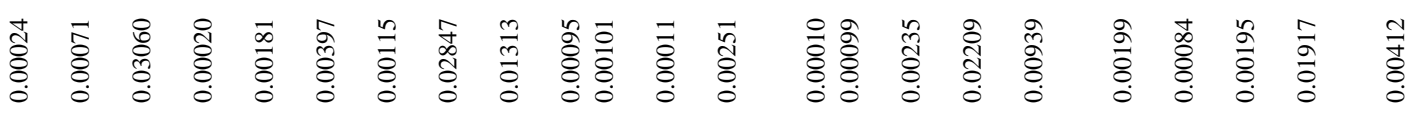

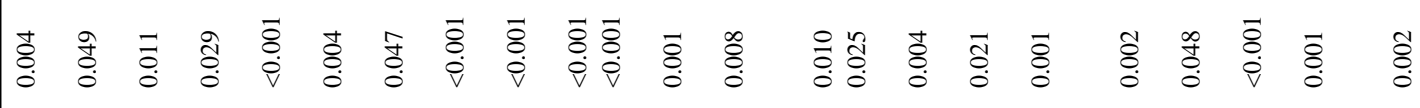

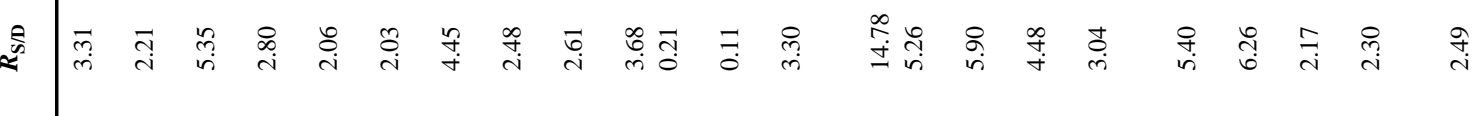

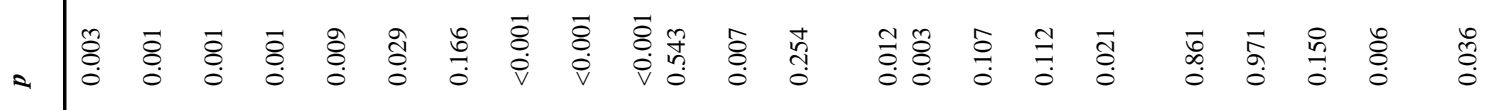

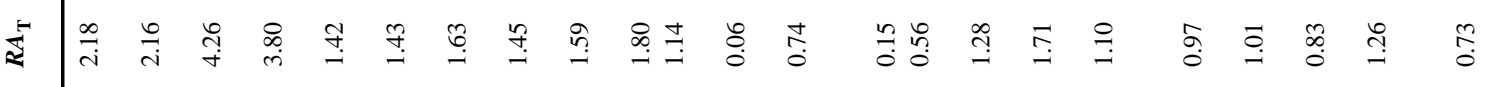

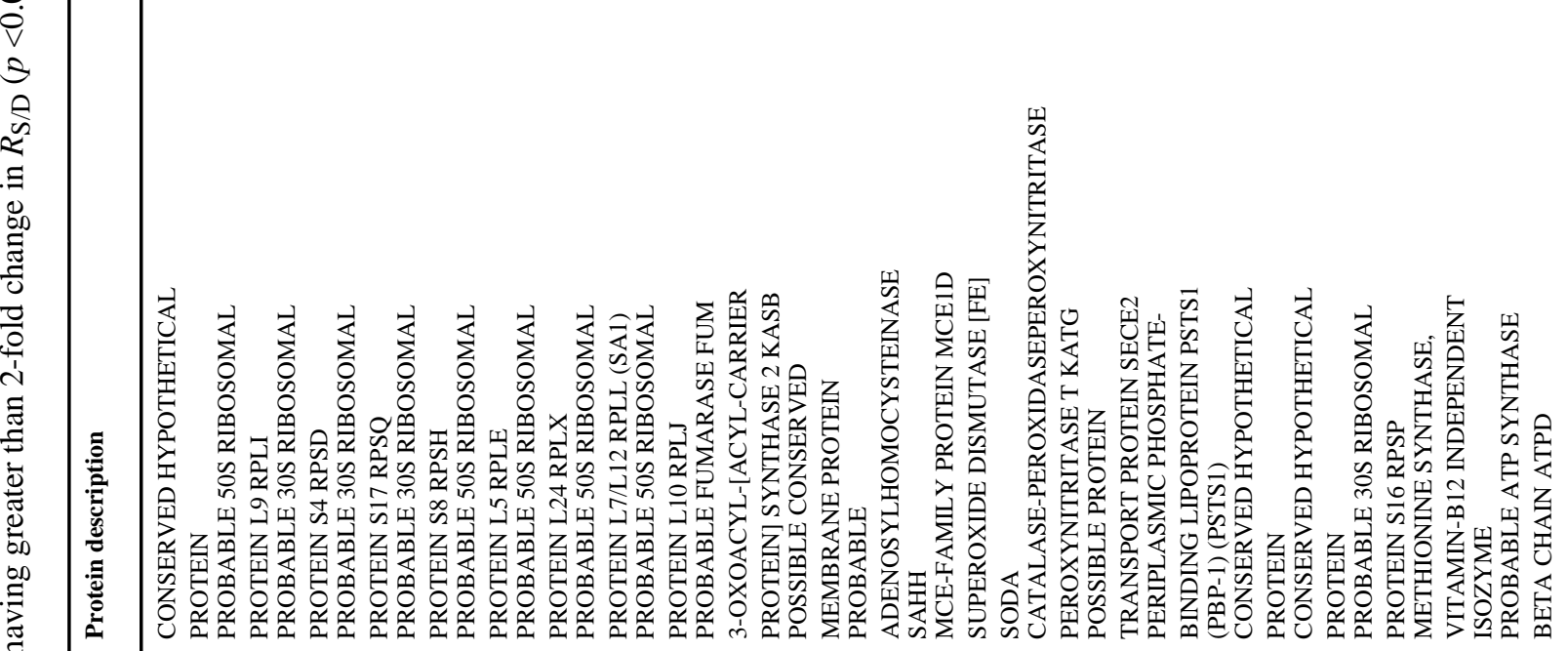

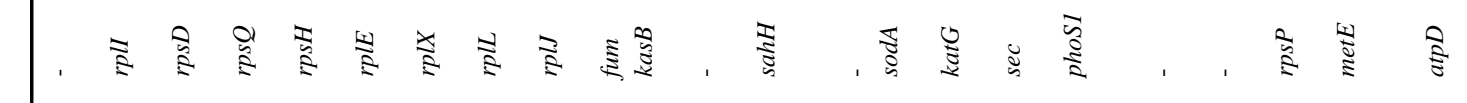

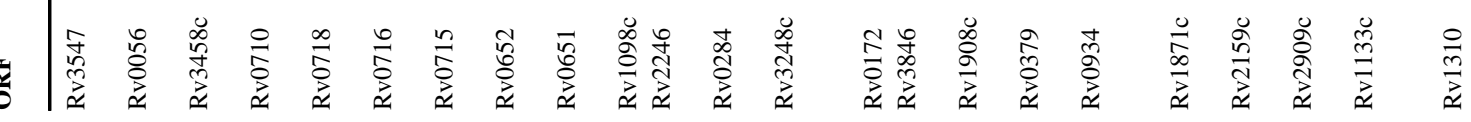


Rao et al.

Page 20

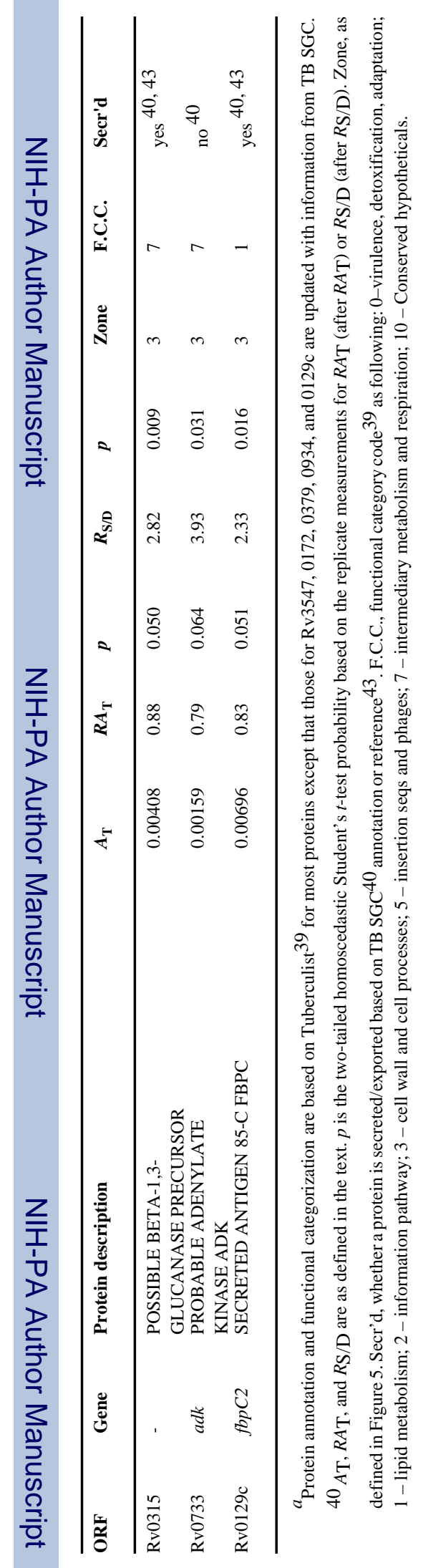

Anal Chem. Author manuscript; available in PMC 2009 October 27. 